\title{
Leaving Buddhism
}

\author{
Monica Lindberg Falk
}

Leaving Buddhism is a theme seldom addressed in Buddhist studies. Buddhism is generally perceived as a tolerant religion and followers are encouraged to scrutinise the Buddhist teachings and are free to leave the Buddhist faith. Buddhism does not sanction violence against apostates, there is no formal religious pretext for apostasy and Buddhism has not developed a concept of apostasy. However, for people who do apostasies from Buddhism, the worst consequences they suffer tend to be negative reactions from the family, including the risk of being ignored and shut out from family and community activities.

The Buddha's (c. 480 BCE-c. 400 BCE $)^{1}$ attitude to apostasy is represented by an account of a meeting with one of the Buddha's attendants Sunakkhatta. He was a disciple of the Buddha, but after a while he became dissatisfied with the Buddha's practice and decided to renounce the teacher and his teaching. Sunakkhatta came to the Buddha and said: "Lord, I am leaving you, I am no longer living by your teachings." The Buddha responded to this declaration by asking Sunakkhatta following questions: "Did I ever say to you; come, live by my teachings?" Sunakkhatta: "No Lord." The Buddha: "Then did you ever say to me that you wished to live by my teachings?" Sunakkhatta: "No Lord." The Buddha: "That being the case, who are you and what are you giving up, you foolish man?" (Digha Nikaya, II I 2-3). Sunakkhatta's defection occurred when the Buddha was eighty years old and that was his last year in life (Batchelor 2015: 172). Neither in this case nor others did the Buddha suggest that apostates should be punished.

The Buddhist traditions are so wide, diverse and multiplex that it often makes sense to refer to Buddhism in the plural form (see Strong 2015). Buddhism(s) is broadly divided into Theravada, Mahayana and Vajrayana traditions and these traditions are historically evolved and culturally embodied. Because of the great diversity within the Buddhist traditions, this chapter on

1 The exact dates of Siddhartha Gotama Buddha's birth and death are uncertain. Heinz Bechert and Richard Gombrich (1991) dating is с. 480 ВСЕ-400 с. ВСЕ, but the traditional dating is often eighty years earlier. 
apostasy in Buddhism focuses mainly on the oldest tradition, Theravada Buddhism. It deals with Buddhist monks and nuns who have left or been expelled from the Buddhist congregation, sangha. It gives examples of lay people who left Buddhism and converted to Christianity and deals with what could be called forced or ascribed apostasy.

\section{$2 \quad$ Key Terms}

Buddhism has no specific word for conversion. However, in the Buddhist collection of Middle-length Discourses of the Buddha, Majjhima Nikaya, a new convert to Buddhism describes himself as having "gone over to the discipleship," savakattam upagato, of the Buddha (Nanamoli 2015: 486). ${ }^{2}$

From the time of the Buddha right up till today people both express their intention to become Buddhists and mark their entry into the Buddhist faith by taking the three refuges, tisarana: I take refuge in the Buddha. I take refuge in the Dhamma (the teachings of the Buddha). I take refuge in the Sangha. This statement is said three times as a reaffirmation that the person is sincere and committed. Lay people receive the five Buddhist precepts from the ordained community: To refrain from killing, stealing, lying, using intoxicants and improper sexual conduct (Harvey 2000: 66-79). For lay people there are no formalities to leave Buddhism and they simply cease receiving the Buddhist precepts and taking refuge in the triple gem: Buddha, Dhamma, Sangha.

The sangha was originally a fourfold congregation of; Buddhist monks, bhikkhu, nuns bhikkhuni, laymen, upasaka, and laywomen, upasika. Today the sangha consists of the ordained community and in Thailand the sangha refers to the congregation of monks. Many Pali and Sanskrit terms have been incorporated into the local languages for example the bhikkhu, bhikkhuni and Buddhist terms used in this chapter are Pali terms and used in Theravada Buddhist countries. Women have never been included in the Thai Buddhist sang$h a$. The sangha is male and has a hierarchical structure and includes every village and monastery in Thailand. Lay people and monastics have commonly had close bonds (Samuels 2010). Lay people give donations, dana, and support the ordained community on a daily basis with food and other necessities. The sangha cares about the lay community and provides teaching and guidance for the laity, and it is significant that the renouncers are a "field of merit" for lay people (Harvey 2013: 314).

2 Most Buddhist terms are given in their Pali spellings. 
In Buddhism, a person generates kammic fruitfulness by his or her own deeds. The monastic life is acknowledged as a generally higher level of virtue than lay life. The monastics has the best environment and support to develop under the guidance of the Buddhist teachings and disciplinary rules (Harvey 2000: 89). Being excluded from the sangha is a punishment and forced apostasy. It means leaving the monastic life and that includes access to ordination.

The ordination ceremony marks a person's entry into the sangha. Buddhist ordination has two steps: first pabbajja, going forth, and second upasampa$d a$, higher ordination as fully ordained monk or nun, bhikkhu or bhikkhuni. The monks' ordination ceremony is led by a monk appointed by the sangha as qualified to be in charge of ordinations, upajjhayo. An ordination for nuns, bhikkhuni, is led by a long-standing and qualified nun, pavattini (Horner 1990: 138-139). A so-called dual ordination is required for the ordination of bhikkhu$n i$ and that means that a bhikkhuni aspirant must ask both the female and the male sanghas for ordination (Holt 1999: 140-142). Ordaining monks and nuns without the right to do so has severe consequences (Gethin 1998: 87).

Newly ordained monks and nuns should spend at least the next five years in "dependence," nissaya, on their teacher who will train them and introduce them to the norms of monastic life. According to the vinaya (monastic rules), if a monk or a nun wishes to return to the lay state, he or she only has to inform his/her fellow monks or nuns of that decision, formally disrobe before them and leave the monastery. In practice, in all Buddhist countries, monks who disrobe (other than those who are temporarily ordained) are looked upon with considerable disapproval (Thanissaro 1994).

A person's fortune and misfortune in life, including leaving Buddhism, are explained by kamma. The Pali word kamma means action and in the Buddhist doctrine refers to a person's intentional mental, verbal or bodily acts. The intentional actions are believed to result in a person's state of being. Also in the Thai usage, the consequences of morally relevant actions of the past, including past lives, explain a person's contemporary life. The Thai concept of religious merit, bun, is used as a motivation for living according to the Buddhist precepts and a lack of bun is the reason, for example, for leaving Buddhism.

\section{3}

\section{Historical Developments}

Buddhism comes from an Indian renunciation tradition and the most important carriers of the Buddhist ways and practice are the sangha with its monks and nuns who transmit the teaching (Gethin 1998: 85). Approximately a hundred years after the death of The Buddha, Siddhartha Gotama, certain 
differences arose in the sangha, which gradually led to the development of a number of monastic groups (Harvey 2013: 2). However, all Buddhist traditions trace their ordination-line back to the early Buddhist groups. Theravada means the teachings of the elders and this tradition is particular about keeping the early Buddhist teaching and the focus is on attaining enlightenment, nibbana, by using dhamma as the guide for living. Theravada is practised by the majority of the population in Sri Lanka, Cambodia, Laos, Myanmar and Thailand. Theravada is characterised by a psychological understanding of human nature, and emphases a meditative approach. The three trainings of ethical conduct, meditation and insight-wisdom are central.

Around the beginning of the Christian era Mahayana Buddhism developed. In contrast to Theravada Buddhism, Mahayana Buddhism is more of an umbrella body for a great variety of schools found in China, Korea and Japan. Mahayana followers made alterations in the Buddhist texts and interpretation of the suttas, discourses, and the vinaya, discipline rules. They rejected certain portions of the Buddhist canon which had been accepted in the Buddhist First Council held in 400 BCE, just after the Buddha's death. The third tradition, Vajrayanam, is a form of Buddhism that is predominant in the Himalayan nations of Tibet, Nepal, Bhutan, and also Mongolia. Buddhism first appeared in Tibet in the seventh century but it did not take root and it was not until the eleventh century the Vajrayana Buddhism was established and developed into lineages. The names of the four major Tibetan Buddhist lineages are Nyingmapa, Sakya-pa, Kagyu-pa and Gelug-pa.

Buddhism is believed to have come to what is now Thailand as early as $25^{\circ}$ BCE (Harvey 2013: 199). Since then, Theravada Buddhism has played a significant role both culturally and socially. Buddhism has been widely adopted as a state sponsored religion and an organised way of social life by the majority of people living in Thailand. Thai Buddhism is formally divided into the Mahanikai and Thammayut Orders.

The Buddha established an ordination lineage for women but when the Theravada bhikkhuni ordination lineage was considered broken it was no longer possible for women to be ordained in the Theravada tradition. However, women had access to ordination in the Mahayana tradition. A global bhikkhuni movement was founded in the 1980 s and since the late 1990s the bhikkhuni ordination has been revived and it is possible for women to receive ordination in the Theravada tradition. Bhikkhunis are not recognized by the Thai sangha and monks who have ordained women in Thailand have been forced to leave the Thai sangha (Kabilsingh 1991: 45-46). Women are excluded from the Thai sangha but local Buddhist nuns, mae chis, have existed in Thailand for centuries. Mae chis have a subordinated position at Thai temples and have during 
recent decades begun to take advantage of their position outside the sangha and established their own nunneries and created better circumstances for themselves (Falk 2007).

One example of the strength of the Thai Buddhist sangha became evident in the aftermath of the 2004 Indian Ocean tsunami where religion became important for the survivors' recovery (Falk 2015). Communities in the tsunami-hit areas in Asia were predominantly Muslim, Buddhist or Hindu, and religious organisation of all kinds raised enormous amounts of money and went to the affected areas to distribute aid. Among them, there were some evangelical Christian groups who tried to exploit the disaster for their own gains, through proselytising, which exacerbated existing religious conflicts or created new ones (Falk 2015: 144-145).

\section{$4 \quad$ Major Controversies and Significant Case Studies}

In Thailand some of the major controversies have resulted in cases where Buddhist monks have been forced to leave the sangha. The controversies have been over issues that violate the Thai Buddhist legislation and that have concerned the Theravada Buddhist teaching, political actions involving monastics, unlawful financial issues, ordination without having been appointed preceptor by the sangha, and giving women novice and higher ordination.

During the Cold War, monks were accused of collaboration with Communist rebels which was a threat to national security and Phra Phimontham (19011992), the abbot of Wat Mahadhatu, was defrocked and imprisoned (Jackson 1989: 100). Buddhadasa Bhikkhu (1906-1993) was also subject to similar allegations from the Thai government (Ito 2012: 180, 185). Phra Bodhiraksa (born 1934) the founder of the Buddhist group Santi Asoke left the sangha and that led to serious controversies and punishment from the sangha (Heikkilä-Horn 1996: 6o-67). They were perceived as apostates. Another longstanding controversy is between the Buddhist movement Wat Phra Dhammakaya temple and the Thai sangha. The temple is accused of money laundry, illegal land transactions, corruption and for introducing elements from Mahayana Buddhism, which is against the Thai Buddhist legislation (Scott 2009: 129-156).

One major controversy that the Thai sangha has had to handle over the last decades is about ordaining women. In 2001 the first Thai woman received bhikkhuni ordination from Theravada monks and nuns in an Asian country. The bhikkhuni movement is a global movement and has been successful in re-establishing the bhikkhuni ordination. In recent decades increasing numbers of women have received bhikkhuni ordination especially in Sri Lanka but 
also in Thailand. Thai monks who give women bhikkhuni ordination risk being expelled from the sangha. Before the revival of bhikkhuni ordination some Thai women went abroad and received bhiksuni ordination in the Mahayana tradition. Returning to Thailand as bhiksunis they were perceived as having apostasised from Theravada Buddhism and were considered belonging to the Mahayana tradition.

One of the most important and venerated religious reformers was the monk Buddhadasa Bhikkhu (1906-1993). Buddhadasa did not leave Buddhism but he left "mainstream" Buddhism, the way Buddhism was understood and practised in central Thailand. He reconceptualised fundamental Buddhist concepts and developed a role quite independent of the sangha. Buddhadasa was critical of what he saw as mainstream Buddhism and in the 196os and 1970s, he was accused of being a communist, as were many of the wandering monks, thudong monks. Buddhadasa lived in the south of Thailand, and was probably saved by living and teaching far from the centre of power in Bangkok and by his increasingly broad, non-politicised popularity (Swearer 1999: 216-217). He had also a great network of people from other religions and he was engaged in interfaith dialogues.

The temple Wat Phra Dhammakaya, in Thailand and abroad, has raised enormous sums of money over the years, and is one example of phuttha phanit, a term that has been used since the late 1980 os to define commercialising Buddhism (see Kitiarsa 2008). Wat Phra Dhammakaya has succeeded in attracting well-off followers from all over Thailand, but they have not accomplished creating peace in their own neighbouring area. There have been disputes over land-tenure and compensation between Wat Phra Dhammakaya and nearby land-renting farmers in 1985-1989. The Wat Phra Dhammakaya movement is today still highly controversial. The temple has been under investigation for having misused the temple funds and the Abbot was suspended because of criminal charges against him and the temple. The Dhammakaya is also accused of violating the Theravada Buddhist teachings and claims that nibbana is a permanent heaven is contrary to the understanding of Theravada Buddhism, although that idea is found in some Mahahayanist groups (Scott 2009: 135-136, 146-149).

The Dhammakaya temple has been embroiled in a money laundering scandal and its founder has refused to meet the police for questioning. Former abbot Phra Dhammachayo (born 1944) faces charges of conspiracy to launder money and receive stolen goods, as well as taking over land unlawfully to build meditation centres. The Thai police have raided the main temple complex on several occasions but without result. The leading monk Dhammajayo has not been found in his quarters. The monk is on the run from more than 300 charges, 
including a multibillion accusation of money laundering. He was stripped of monastic rank by the Thai King in March 2017 and he risks being imprisoned (Bangkok Post, 6 March 2017).

The Buddhist group Santi Asoke's members have left the sangha. They distinguish themselves from "mainstream" Thai Buddhists by living in communities of dhamma families that include monks, nuns and male and female lay people, very much like the original ideal sangha. Santi Asoke was set up as an independent Buddhist temple and had serious disagreements with the Thai sangha authorities, Maha Thera Samakhom. They led to the prosecution of the founder and leader Phra Bodhiraksa. In June 1989, he was brought to court and sentenced to leave the monkhood. It was the regional monastic leaders who called for Phra Bodhiraksa to be defrocked, and the Thai sangha initiated legal proceedings against him for violating the vinaya and distorting Buddhist principles. He was even incarcerated for a period. He escaped formal defrocking after voluntarily changing the colour of his robe from brown to white (Heikkilä-Horn 1996). Santi Asoke is also controversial for ordaining women as ten-precept nuns known as sikkhamats, similar to novice bhikkhunis (HeikkiläHorn 2015).

Giving women bhikkhuni ordination has been a major controversy not only in Thailand but also in other Asian countries. Charsumarn Kabilsingh, later Dhammananda Bhikkhuni, was the first Thai woman who received Theravada bhikkhuni ordination in Sri Lanka. She was well known before her ordination for advocating women's rights to full ordination. Her ordination created a commotion and there were attempts to make her life as a bhikkhuni impossible (Falk 2007). Currently there are about one hundred seventy-five Thai bhikkhunis and bhikkhuni ordinations have also taken place in Thailand. Since 1928 it is forbidden for Thai monks to ordain women as bhikkhunis and Thai monks who are involved in bhikkhuni ordination risk being defrocked and expelled from the sangha. The rule was established after two young sisters had received novice bhikkhuni ordination from a Thai monk (Kabilsingh 1991: 45-48). That incident inspired the sangha's supreme council to pass an order forbidding any monks from giving women novice or full ordination as bhikkhuni, and that rule is still valid.

Voramai Kabilsingh also called Ta Tao Fa Tzu (1908-2003) was a journalist and become a mae chi in 1954 when her daughter Chatsumarn (mentioned above) was 10 years old. She established Songdhammakalyani Monastery in Thailand and in 1970 Voramai Kabilsingh went to Taiwan and received bhiksuni ordination in the Mahayana Dharmaguptaka lineage. Chatsumarn Kabilsingh grew up with her mother at the nunnery. She went abroad for higher education, later she married, had children and became a professor at a top university 
in Bangkok. Throughout her professional life she worked for Buddhist women's right to bhikkhuni ordination. She had long planned to live an ordained life after retirement and before she was ordained she carefully considered in which tradition she should ask for ordination. She wanted to be accepted as a bhikkhuni in Thailand and therefore she wanted to be ordained in the Theravada lineage. Her mother was a Mahayana bhiksuni and she saw that she had many supporters but no followers as a result of being ordained in the Mahayana tradition. In the end of 1990 s it was open for women to receive bhikkhuni ordination in Sri Lanka and Chatsumarn Kabilsingh decided to seek novice ordination there (Achakulwisut 2001). However, the Thai sangha still persists in not recognising her ordination and her status as a Theravada bhikkhuni. For Chatsumarn Kabilsingh, now Dhammananda Bhikkhuni, the debate about the continuation of the bhikkhuni/bhikksuni lineage is academic. She said: "What I'm trying to prove is that during the Buddha's time there was no Mahayana or Theravada, and ordination was given to women, period (Janssen 2001)."

This part ends with a case study about Thai lay people who left Buddhism in the wake of the 2004 Indian Ocean tsunami. All kinds of Christian missionaries operated in the affected areas after the tsunami. Some Christian groups came to provide aid, whereas some came to convert. Survivors from the hardest-hit area told about their experiences of being approached by Christian missionaries. They had been offered money and material aid if they left Buddhism and converted to Christianity. Some survivors agreed to convert, others said they did not want to "sell their Buddhist faith" which is very much the base of their identity. Those Buddhist survivors who had converted and thereby received money and material goods in return were looked upon as corrupt and their neighbours were disappointed and said they had lost their respect for them. The Buddhist temples were still open to the converts but the converts were forbidden by the Christian priests to listen to the Buddhist monks and partake in Buddhist ceremonies. That was something that the Thai Buddhists found strange. The conversion created divisions within those small villages and a lack of trust between the converts and lay people occurred (Falk 2013: 41-42).

Both monks and lay people explained the conversion as the converts' lack of bun, religious merit. To be Buddhist is considered as signifying being meritorious, and converting or leaving the ordained state was seen as that person's "good merit" had come to an end. The majority of the Thai Buddhist monks in the tsunami hit areas also used kamma to explain the situation and they kept a low profile in relation to the great influx of Christian missionaries. They did not express any resentment against Christian priests or those Buddhist followers who converted. The majority of Buddhist monks interviewed by me in the tsunami hit area had a relaxed attitude towards conversion. One monk from 
the Asoke group who had come to assist the survivors explained that Buddhism does not prohibit anyone who comes to do good deeds. Accordingly, the conversion to another faith is not a problem if laypeople find that it is beneficial (see Falk 2013; 2015).

However, Christian missionaries traded aid for faith and the conversion of Buddhists to Christianity made not only divisions at the village level but it also created rifts within families. A study on Thai Buddhist women in the north-east of Thailand who converted to Islam reports difficulties in relation with their families. The convert survivors from the tsunami in the south of Thailand and women who had converted to Islam in the north-east experienced the same difficulties of not having the permission from their new religions to attend Buddhist ceremonies. Thai cultural values prescribe that daughters and sons should be at their parents' funerals, to show that they respect their parents. Children are severely judged by others if they do not do so. But Muslims cannot attend Buddhist services, and the converts are caught in a bind between two value systems (Charoenwong et al. 2017: 125).

Lay people leave Buddhism for different reasons and in the post-tsunami situation forced conversion of Buddhists to Christianity has resulted in the exclusion of converts from their community-based, as well as family-cantered, Buddhist ceremonies and activities that would have probably helped them as their culturally accepted coping methods.

Buddhist texts are commonly divided into canonical and non-canonical texts. The canonical texts are believed to be the actual teachings of the Buddha. The Tipitaka, the Pali canon, is considered the earliest Buddhist teachings and recognized as canonical in the Theravada tradition. The Tipitaka is divided in three groups of teachings, sometimes called the three baskets and it was transferred orally, being and written down about 300 вСE. The Tipitaka, includes the Vinaya pitaka, that deals with the discipline rules for monks, nuns, and guidelines for the interaction between the sanga and laity. The Sutta Pitaka, contains the Buddha's teachings on doctrine and behaviour, with a focus on meditation techniques. Abhidhamma pitaka is about advanced teachings and higher knowledge of Buddhist philosophy and psychology.

The Buddha's view on apostasy mentioned above is from the Sutta Pitaka, found in the Digha Nikaya that is one of the five collections (nikayas) and an assembly of long discourses. The text is in the Patika Sutta: About Patikaputta the Charlatan (Walshe 1995: 371-378). 
There are two translations to English: Dialogues of the Buddha translated by T.W. and C.A.F. Rhys Davids (1899-1921), in three volumes. Published by the Pali Text Society and Thus Have I Heard: The Long Discourses of the Buddha translated by Maurice Walshe $(1987,1995)$.

Buddhadasa Bhikkhu's work was based on extensive research of the Pali text Canon and commentary, especially of the Buddha's Discourses (Sutta Pitaka), followed by personal experiment and practice with these teachings. His publications are huge and some of his most well-known books are: Handbook of Mankind, Heart-wood from the Bo Tree, Keys to Natural Truth, Mindfulness with Breathing, and Paticcasamuppada: Practical Dependent Origination.

Some major work for analysing the position of women in Buddhism, that give a background to why women have "left" their Buddhist tradition and sought other ways to access ordination are: Women Under Primitive Buddhism by Isaline Blew Horner (1930) which is a major historical work on laywomen and monastics based on canonical literature including the Vinaya Pitaka (Basket of Discipline). Buddhism After Patriarchy, A Feminist History, Analysis and Reconstruction of Buddhism by Rita Gross (1993) is another important book that surveys the part women have played in Buddhism historically and completes the Buddhist historical record by bringing in women who usually are absent from histories of Buddhism. Women in Buddhism: Images of the Feminine in the Mahayana Tradition, by Diana Y. Paul (1979) offers a number of highly interesting Buddhist texts concerned with Mahayana Buddhism. First Buddhist Women, Poems and Stories of Awakening by Susan Murcott (1991) traces the journey of the first Buddhist women from the Therigatha, the earliest known collection of women's religious poetry. Bhikkhuni Patimokkha of the Six Schools by Chatsumarn Kabilsingh is a key work that contains translations of one of the oldest texts of the Buddhist canon and compares the different Buddhist schools.

Buddhadasa Bhikkhu, lay name Nguam Phanit, (1906-1993) is regarded as one of the most influential modernisers of Thai Buddhism (Jackson 2003; Ito 2012). He was born, in Chaiya District, Surat Thani province in southern Thailand. His father was of second-generation Thai Chinese (Hokkien) ancestry and his mother was Thai. Buddhadasa renounced lay life when he was twenty years old. He studied the Buddhist doctrine in Bangkok but was disappointed with the urban temples and how the temples were managed. He returned to Surat Thani and established Suan Mokkhabalarama (The Grove of the Power of Liberation) in 1932. He left what the Thai sangha represented, and abandoned 
ritualism and the internal sangha politics. Buddhadasa developed a role independent of the religious hierarchy and reformed basic beliefs, values, and practices (King 1996: 402). His new interpretations of central Buddhist concepts such as kamma and nibbana were not in line with the orthodox Thai teachings and challenged the sangha (Ito 2012: 16). He integrated modern views and a distinctive forest tradition and his interpretation of canonical texts attracted an educated following among lay people. Buddhadasa's Buddhist interpretation has constituted a contrast to supernatural formulations of Buddhism that legitimate wealth and power with reference to kammic explanations. He reconceptualised fundamental Buddhist concepts and he described central Buddhist concepts differently from the traditional Thai understanding.

Bodhiraksa, lay name Mongkol "Rak" Rakpong, was born in 1934 in Ubon Ratchathani province in Northeastern Thailand to a Sino-Thai family. Before he was ordained, at the age of thirty-six years, he had been a composer of popular music and a television celebrity. In 1970 he received ordination in the Thammayutnikai, one of the two Thai Buddhist "sects" (nikai). He resigned from the Thammayutnikai and three years later he was re-ordained in the other "sect" Mahanikai. Phra Bodhiraksa openly criticised the Mahanikai monks for eating meat, magic practices and consumerism. The group distinguished themselves from other Thai Buddhist groups and provoked criticism from the sangha. In 1975 Phra Bodhiraksa and his group left the state sangha organisation and established Santi Asoke as an independent group. The group has subsequently seen regarded as "outlawed." He reinterpreted the Pali canon and the established Buddhist scholars blamed him for misunderstanding and misinterpreting the Buddhist scriptures. In 1988 the members of Santi Asoke were accused of being heretics. In 1989 a trial started that the Asoke group was not Buddhist and there was an ongoing court case against Bodhiraksa and his group for seven years (Heikkilä-Horn 1996). Most threatening to the sangha was probably Bodhiraksa's action of ordaining monks and novices without being officially designated as having this right. Those activities together with his claim to have attained enlightenment are offences for which a monk can be expelled from the order (See Taylor 1989: 117-118; Keyes 1999: 24). Many saw the trial as a conflict between a corrupt sangha seeking to uphold its entrenched power and an ethically strict Buddhist renunciate aiming to purify and revitalise the religious order (Jackson 1997: 78). Bodhiraksa points to the possibility of a modern Buddhism without the sangha.

Bhikkhuni Dhammananda, lay name Chatsumarn Kabilsingh was born in 1944 and was brought up in Nakhon Pathom in Thailand. Her father was a politician and member of parliament and ordained later as a Theravada monk. Her mother was a bhiksuni and since Chatsumarn was ten years old she had lived 
in the temple. Chatsumarn Kabilsingh received her Master of Arts in religion from McMaster University in Canada and received her doctoral grade in Buddhism from Magadh University in India. She married, had three sons and six grandchildren. Chatsumarn taught for twenty-seven years at Thammasat University in Bangkok, Thailand, at the Department of Philosophy and Religion. She has published widely on gender and Buddhism. She sought early retirement from the university in 2000 and she also resigned from the Thai television where she had been working with Buddhist programmes for many years (Achakulwisut 2001; Yasodhara 2001: 17). In 2001, she received samaneri (female novice) ordination and in 2003 she received higher bhikkhuni ordination, upasampada, in Sri Lanka. She is the abbess of Songdhammakalyani Monastery in Nakhon Pathom, Thailand.

\section{$7 \quad$ Conclusion}

This chapter has explored apostasy from Buddhism and addressed circumstances that have caused monastics and lay people to apostasies. The story about Sunakkhatta, related in the Digha Nikaya, displays that apostasy was not disciplined during the Buddha's time and Buddhism does not sanction violence against apostates. Leaving Buddhism is still straightforward, and the difficulties lay people face when leaving Buddhism are related to their private lives and their relationships with family and friends. That was something that became evident among those who left Buddhism and converted to Christianity in the aftermath of the 2004 Indian Ocean tsunami.

In spite of the fact that sanctions against apostasy are absent in the Buddhist canonical texts, apostasy has developed in the Buddhist traditions. In Thailand for instance, apostasy is considered as being expressed in acts of not following what is judged as Theravada Buddhism, and the Thai sangha excludes monastics who deviate from the Theravada teaching. The Thai sangha has strict rules about ordination into the Buddhist monkhood and Buddhist monks who give ordination without having the stipulated credentials, face being defrocked from monkhood. It is even more severe for monks to give women bhikkhuni ordination, and it is illegal under all circumstances and leads to punishment from the sangha.

The group Santi Asoke is an example of a Buddhist group that have been excommunicated for violating the sangha's legislation. Another example is Wat Phra Dhammakaya, a group that is much larger than Santi Asoke, whose members are accused of not conforming to Theravada Buddhism. Moreover, the leadership is under suspicion of criminal offences and the abbot has been 
considered as apostasising and formally been stripped of his ranks and condemned to exile.

It is not always clear for Buddhists themselves that they are considered to have left Buddhism. That was something that Buddhist women experienced when they have gone abroad and received bhiksuni ordination in the Mahayana tradition, since it was not possible for women to be ordained in the Theravada tradition. They still identified themselves as Theravada Buddhists but when they returned to Thailand they were considered by others as having apostasised from Theravada Buddhism.

\section{References}

Achakulwisut, A. 2001. "A path less travelled." Bangkok Post, April, 17.

Bangkok Post. 6 March 2017 and 22 December 2017.

Batchelor, S. 2015. After Buddhism: Rethinking the Dharma for a Secular Age. New Haven \& London: Yale University Press.

Bechert, H. and R. Gombrich. 1991. The world of Buddhism: Buddhist monks and nuns in society and culture. London: Thames and Hudson.

Charoenwong, S., S. Chirawatkul and L. Manderson. 2017. "Emotional Well-Being Following Religious Conversion Among Women in Northeast Thailand." Journal of Religion and Health. 56:1, 118-129.

Digha Nikaya. T.W. Rhys Davids, J.E. Carpenter, eds. Pali Text Society, London 1890-1911.

Falk, M.L. 2007. Making Fields of Merit: Buddhist Female Ascetics and Gendered Orders in Thailand. Copenhagen/Washington: NIAS Press/University of Washington Press.

Falk, M.L. 2013. "Thai Buddhists' Encounters with International Relief Work in Posttsunami Thailand." In H. Kawanami and G. Samuel, eds, Buddhism, International Relief Work and Civil Society. New York: Palgrave Macmillan, 27-49.

Falk, M.L. 2015. Post-Tsunami Recovery in Thailand: Socio-Cultural Responses. London and New York: Routledge.

Gethin, R. 1998. The Foundations of Buddhism. Oxford and New York: Oxford University Press.

Gross, R.M. 1993. Buddhism after Patriarchy: A Feminist History, Analyses, and Reconstruction of Buddhism. Albany, N.Y.: State University of New York Press.

Harvey, P. 2000. An Introduction to Buddhist Ethics: Foundations, Values and Issues. Cambridge: Cambridge University Press.

Harvey, P. 2013. An Introduction to Buddhism: Teachings, History and Practices. Cambridge: Cambridge University Press.

Heikkilä-Horn, M.-L. 1996. Santi Asoke Buddhism and Thai State Response. Turku: Åbo Akademi University Press. 
Heikkilä-Horn, M.-L. 2015. "Religious Discrimination and Women in Asoke Buddhist Group in Thailand." In Eunice Rodriguez and Barbara Wejnert, eds, Enabling Gender Equality: Future Generations of the Global World. Research in Political Sociology. Bingley, United Kingdom: Emerald Group Publishing, 172-180.

Holt, J.C. 1999 [1981]. Discipline: The Canonical Buddhism of the Vinayapitaka. Dalhi: Motilal Banarsidass Publishers.

Horner, I.B. 1990 [1930]. Women under Primitive Buddhism: Laywomen and Almswomen. Delhi: Motilal Banarsidass.

Ito, T. 2012. Modern Thai Buddhism and Buddhadasa Bhikkhu: A Social History. Singapore: NUS press.

Jackson, P.A. 1989. Buddhism, Legitimation, and Conflict: The Political Functions of Urban Thai Buddhism. Singapore: Institute of southeast Asian Studies.

Janssen, P. 2001. "Thai novice attempts to launch female monkhood." Yasodhara. 17:3, $15^{-16 .}$

Kabilsingh, C. 1991. Thai Women in Buddhism. Berkeley, California: Parallax Press.

Keyes, C. F. 1999. "Buddhism fragmented: Thai Buddhism and political order since the 1970s". Keynote Address presented at the Seventh International Conference on Thai Studies, Amsterdam 4-8 July.

King, S.B. 1996. "Conclusion: Buddhist social activism.” In C.S. Queen and S.B. King, eds, Engaged Buddhism: Buddhist Liberation Movements in Asia. Albany: State University of New York Press, 321-329.

Kitiarsa, P. ed. 2008. Religious Commodifications in Asia: Marketing Gods. London and New York: Routledge.

Majjhima Nikaya. Ed. V. Trenchner and R. Chalmers, Pali Text Society, London 1887-1902.

Nanamoli, Bhikkhu, original translation revised by Bhikkhu Bodhi. 2015 [1995]: The Middle Length Discourses of the Buddha: A Translation of the Majjhima Nikaya. Massachusetts: Wisdom Publications.

Paul, D.Y. 1979. Women in Buddhism: Images of the Feminine in the Mahayana Tradition. Berkeley and Los Angeles: University of California Press.

The Buddhist Monastic Code: The Patimokkha Training Rules Translated and Explained. 1993. Bangkok: The Mahamakuta Educational Council, The Buddhist University Thailand.

Santikaro Bhikkhu. 1996. "Buddhadasa Bhikkhu: Life and society through the natural eyes of voidness." In C.S. Queen and S.B. King eds., Engaged Buddhism: Buddhist Liberation Movements in Asia. Albany: State University of New York Press, 147-193.

Taylor, J.L. 1989. "Contemporary urban Buddhist 'cults' and the socio-political order in Thailand." In Mankind 19:2, 112-125.

Thanissaro Bhikkhu. 2013 [1994]. The Buddhist Monastic Code I. California: Metta Forest Monastery. 
Samuels, J. 2010. Attracting the Heart: Social Relations and the Aesthetics of Emotions in Sri Lankan Monastic Culture. Honolulu: University of Hawai'i Press.

Sangharakshita. 1994. The Meaning of Conversion in Buddhism. Birmingham: Windhorse Publication.

Scott, R.M. 2009. Nirvana for Sale? Buddhism, Wealth, and the Dhammakaya Temple in Contemporary Thailand. New York: State University of New York.

Strong, J.S. 2015. Buddhisms: An Introduction. London: Oneworld Publication.

Swearer, D.S. 1999. "Centre and periphery: Buddhism and politics in modern Thailand." In Ian Harris, ed, Buddhism and Politics in Twentieth-Century Asia. London and New York: Continuum, 194-228.

Walshe, M. 1995 [1987]. The Long Discourses of the Buddha: A Translation of the Digha Nikaya. Massachusetts: Wisdom Publication.

Yasodhara. 2001. "Feel the beauty of the lotus: An interview with Dhammananda." Yasodhara Newsletter on International Buddhist Women's Activities. 7:3, 67. 